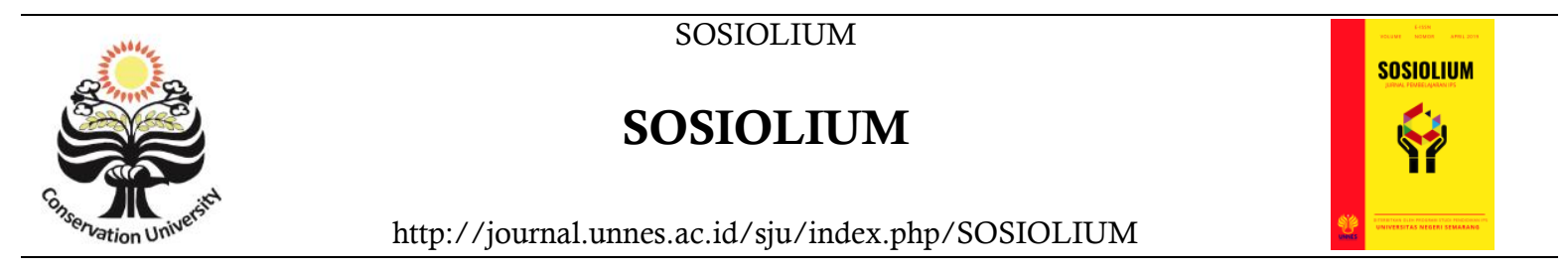

\title{
ANALISIS BUKU TEKS PELAJARAN IPS KELAS VII KURIKULUM 2013 DI SMP SEKECAMATAN NGARGOYOSO KABUPATEN KARANGANYAR JAWA TENGAH
}

\author{
Resa Agustina ${ }^{\bowtie}$, Arif Purnomo \\ Prodi Pendidikan IPS, Fakultas Ilmu Sosial, Universitas Negeri Semarang, Indonesia
}

\begin{tabular}{l}
\hline Info Artikel \\
\hline Sejarah Artikel: \\
Disubmit: Juli 2021 \\
Direvisi: Agustus 2021 \\
Diterima: September \\
2021 \\
\hline Keywords: \\
Textbooks; Material \\
Development; Evaluation \\
Developed; Teacher's \\
Response
\end{tabular}

\begin{abstract}
Abstrak
Buku teks merupakan salah satu sumber belajar yang penting, sehingga dapat mendukung tercapainya tujuan pembelajaran. Setiap mata pelajaran setidaknya memerlukan minimal satu buku teks yang relevan dan berkualitas. Tujuan penelitian ini untuk mengetahui pengembangan materi dan alat evaluasi yang dikembangkan pada buku teks pelajaran IPS. Jenis penelitian yang digunakan, yaitu penelitian deskriptif dengan pendekatan kualitatif. Hasil penelitian menunjukkan bahwa buku yang digunakan di SMP Negeri 1 Ngargoyoso dan SMP Negeri 2 Ngargoyoso masih menggunakan buku teks pelajaran IPS revisi tahun 2016, tetapi dari segi pengembangan materi masih relevan dengan KI dan KD terbaru, yaitu Permendikbud No. 37 Tahun 2018. Alat evaluasi yang digunakan pada kedua buku, yaitu pada ranah kognitif dan ranah psikomotorik. Soal-soal kognitif yang disajikan pada level medium. Serta tanggapan guru terhadap buku teks yang mereka gunakan menunjukkan bahwa buku teks mampu membantu peserta didik dalam proses pembelajaran IPS dari segi materi, tingkat kesulitan soal, dan materi yang disajikan masih relevan dengan lingkungan peserta didik.
\end{abstract}

\begin{abstract}
Textbooks are one of the important learning resources, so they can support the achievement of learning objectives. Each subject requires at least one relevant and quality textbook. The purpose of this study was to determine the development of materials and evaluation tools developed in the social studies textbooks used in SMP Sekecamatan Ngargoyoso and teachers responses to the textbooks they used. The type of research used is descriptive research with a qualitative approach. Collecting datausing interview methods and study documentation. The results show that the books used in SMP Negeri 1 Ngargoyoso and SMP Negeri 2 Ngargoyoso still use the revised social studies textbooks in 2016, but in terms of material development, they are still relevant to the latest KI dan KD, namely Permendikbud number 37 of 2018. The evaluation tools used in the medium level. And the teacher's response to the texts they use shows that the textbooks are able to help students ini the social studies learning process in terms of the material, the level of difficulty of the questions, and the material presented is still relevant to the students environment.
\end{abstract}




\section{PENDAHULUAN}

Meningkatkan kualitas pendidikan, yaitu dengan mewujudkan tujuan pendidikan dri berbagai macam komponen, seperti pendidik, peserta didik, dan bahan ajar. Buku teks merupakan bahan ajar atau sumber belajar yang sering digunakan dalam proses pembelajaran. Proses pembelajaran di kelas, buku teks sering menjadi buku pegangan guru dan peserta didik dan tidak sedikit buku teks dimanfaatkan sebagai referensi utama, sehingga guru harus selektif dalam memilih buku teks yang sesuai dengan pembelajaran dan kurikulum yang berlaku. Saat ini pendidikan di Indonesia menggunakan Kurikulum 2013. Kompetensi Inti dan Kompetensi Dasar setiap mata pelajaran terus diperbarui hingga saat ini Kompetensi Inti dan Kompetensi Dasar terbaru, yaitu Permendikbud No. 37 Tahun 2018. Pembaharuan tersebut memberikan PR bagi pemerintah terkait dan penerbit untuk terus memperbaiki buku teks pelajaran yang mereka edarkan dan perjualbelikan agar relevan dengan Kompetensi Inti dan Kompetensi Dasar terbaru.

Banyak buku teks yang beredar terutama buku teks pelajaran IPS. Hal ini memberikan dampak positif dan dampak negatif. Dampak positifnya, yaitu banyaknya buku yang beredar memberikan kemudahan bagi seluruh kalangan terutama guru dan peserta didik. Guru IPS sendiri untuk mendapatkan bahan ajar dengan berbagai referensi, serta peserta didik bisa mencari buku yang mudah mereka pahami.

Dampak negatifnya, yaitu semakin banyak buku teks yang beredar membingungkan pengguna untuk memilih buku teks yang sesuai dengan kebutuhan. Adanya buku teks ini bisa menyebabkan guru IPS mengajarkan materi hanya terpaku pada buku teks saja, padahal materi pelajaran IPS sangat luas, materi pembelajaran juga diambil dari isu-isu yang ada di dalam masyarakat sendiri. Seperti yang dijelaskan oleh Purnomo, dkk (2020) bahwa guru IPS haruslah menarik dan kreatif dalam memberikan pembelajaran kepada peserta didik dimulai dari materi pelajaran yang diberikan.

Materi pada mata pelajaran IPS memiliki lingkup pembahasan yang luas. Sehingga, materi pada pelajaran IPS terdapat materi kontroversi, untuk itu materi haruslah memuat pandangan yang berupa setiap pendapat harus memiliki dasar yang kuat. Buku teks yang berdedar haruslah memiliki alat evaluasi yang baik yang berupa terdapat soal-soal yang memiliki tingkat berpikir tinggi dan mengasah kreativitas peserta didik dengan aktivitas- aktivitas keterampilan. Setiap sekolah pasti memiliki buku teks yang mereka gunakan sebagai acuan pembelajaran setiap mata pelajaran karena suatu kewajiban atau kesesuaian materi pada buku dengan lingkungan peserta didik.

Berdasarkan latar belakang tersebut, maka peneliti ingin melakukan penelitian dengan judul "Analisis Buku Teks Pelajaran IPS Kelas VII Kurikulum 2013 di SMP Sekecamatan Ngargoyoso Kabupaten Karanganyar Jawa Tengah".

Rumusan masalah dalam penelitian ini yaitu (1) Bagaimanakah pengembangan materi pada buku teks IPS kelas VII kurikulum 2013 di SMP Sekecamatan Ngargoyoso Kabupaten Karanganyar?; (2) Bagaimanakah evaluasi yang dikembangkan pada buku teks IPS kelas VII kurikulum 2013 di SMP Sekecamatan Ngargoyoso Kabupaten Karanganyar?; (3) Bagaimanakah tanggapan guru terhadap buku teks IPS kelas VII kurikulum 2013 di SMP Sekecamatan Ngargoyoso Kabupaten Karanganyar?.

Landasan teorinya, yaitu buku teks pelajaran merupakan buku yang memuat materi mengenai mata pelajaran tertentu, disusun secara sistematis, dan sudah diseleksi berdasarkan tujuan tertentu, disusun sesuai dengan orientasi pembelajaran dan perkembangan pesera didik untuk diasimilasikan (Muslich, 2010).

Schorling dan Batchelder dalam Muslich (2010), menjelaskan empat ciri buku teks yang baik, sebagai berikut. (1) direkomendasikan para guru yang berpengalaman karena buku teks tersebut baik; (2) bahan ajar sesuai dengan tujuan pendidikan, kebutuhan peserta didik, dan kebutuhan masyarakat; (3) cukup banyak berisi teks bacaan, bahan drill, dan latihan atau tugas; dan (4) berisi ilustrasi yang membantu peserta didik untuk belajar.

Gasong (2018) mendefinisikan pembelajaran sebagai seperangkat peristiwa yang dirancang guna memprakarsai, menggiatkan, dan mendukung kegiatan belajar peserta didik. IPS adalah suatu bahan kajian terpadu yang merupakan penyederhanaan, adaptasi, seleksi, dan modifikasi yang diorganisasikan dari konsep dan keterampilan sejarah, geografi, sosiologi, antropologi, dan ekonomi (Fajar, 2002). Pembelajaran IPS merupakan serangkaian proses yang dimana peserta didik belajar mengenai berbagai konsepkonsep penting IPS yang tersusun dari gabungan berbagai disiplin ilmu sosial dan diimplementasikan secara nyata guna 
memecahkan berbagai permasalahan sosial yang ada melalui pengajaran guru IPS.

Materi pada pembelajaran IPS SMP/MTs harus sesuai dengan Kompetensi Inti dan Kompetensi Dasar terbaru, yaitu Permendikbud No. 37 Tahun 2018 yang didalamnya mencakup empat kompetensi, yaitu (1) kompetensi sikap spiritual; (2) sikap sosial; (3) pengetahuan; (4) keterampilan.

Salah sastu aspek penting dalam buku teks pelajaran, yaitu materi. Pengetahuan peserta didik berkaitan dengan pengetahuan faktual, konseptual, dan prosedural (Anderson \& Krathwohl dalam Ramda, 2017). Sehingga, perlunya instrumen guna melihat kesesuaian materi, yaitu berkaitan dengan cakupan materi, keluasan materi, kedalaman materi, keakuratan materi, dan penyajian materi.

Evaluasi merupakan proses penentuan nilai terhadap objek tertentu berdasarkan beragam kriteria yang sudah ditetapkan sebelumnya (Nurhadi dan Suwardi, 2010). Berdasarkan fungsinya, penilaian terdiri dari beberapa jenis, yaitu penilaian formatif, sumatif, diagnostik, selektif, dan penempatan. Penilaian pembelajaran berbasis HOTS, yaitu pada aspek kognitif, afektif, dan psikomotorik.

Aspek kognitif, yaitu terdiri dari pengetahuan $(\mathrm{C} 1)$, pemahaman $(\mathrm{C} 2)$, aplikasi (C3), analisis (C4), evaluasi (C5), dan menciptakan (C6). Aspek afektif, yaitu terdiri dari penerimaan, penanggapan, perhitungan atau penilaian, pengaturan atau pengelolaan, dan bermuatan nilai. Aspek psikomotorik, yaitu terdiri dari meniru, manipulasi, presisi/ketepatan, artikulasi, dan naturalisasi.

\section{METODE}

Jenis penelitian ini adalah penelitian kualitatif deskriptif menggunakan pendekatan studi kasus dengan objek penelitian buku teks pelajaran IPS kelas VII kurikulum 2013, yaitu buku teks pelajaran IPS terbitan Kemendikbud dan terbitan Erlangga seri Mandiri. Latar penelitian di SMP Negeri 1 Ngargoyoso dan SMP Negeri 2 Ngargoyoso. Fokus penelitian ini mengenai pengembangan materi dan evaluasi yang dikembangkan pada buku teks IPS kelas VII kurikulum 2013, serta mengetahui tanggapan guru IPS terhadap buku teks IPS kelas VII kurikulum 2013.

Sumber data dalam penelitian ini, yaitu data primer berupa buku teks terbitan Kemendikbud dan terbitan Erlangga seri Mandiri, serta sumber informan, yaitu guru IPS kelas VII di SMP Negeri 1 Ngargoyoso dan
SMP Negeri 2 Ngargoyoso. Data sekunder berupa artikel-artikel, buku-buku, serta dokumen-dokumen yang berkaitan dengan kurikulum 2013.

Teknik pengumpulan data menggunakan wawancara dan studi dokumentasi. Metode wawancara untuk mengetahui tanggapan guru IPS sedangkan studi dokumentasi untuk mengetahui pengembangan materi dan evaluasi yang dikembangkan pada buku teks pelajaran IPS kelas VII kurikulum 2013. Uji validitas data dalam penelitian ini, meliputi credibility, transferability, dependability, dan confirmability. Analisis data mengggunakan teknik analisis isi.

\section{HASIL DAN PEMBAHASAN}

\section{Pengembangan Materi pada Buku Teks Pelajaran IPS Kelas VII Kurikulum 2013 di SMP Sekecamatan Ngargoyoso Kabupaten}

\section{Karanganyar}

Pengembangan materi yang dianalisis dalam penelitian ini, yaitu cakupan materi, keluasan materi, kedalaman materi, keakuratan materi, dan penyajian materi.

Cakupan materi pada buku teks terbitan Kemendikbud dan terbitan Erlangga seri Mandiri sudah sesuai dengan indikator penilaian, yaitu pada buku teks sudah memiliki kelengkapan pokok yang bisa menunjang $\mathrm{KI}$ dan KD.

Keluasan materi pada buku teks terbitan Kemendikbud dan terbitan Erlangga seri Mandiri sudah sesuai dengan indikator penilaian, yaitu dari segi penyampaian konsep, definisi, prinsip, prosedur, contoh-contoh, dan pelatihan yang ada pada buku teks sesuai dengan kebutuhan materi pokok yang mendukung tercapainya $\mathrm{KI}$ dan $\mathrm{KD}$ dan materi termasuk contoh dan latihan dalam buku teks menjelaskan substansi minimal yang terkandung dalam KI dan KD. Tetapi pada buku teks terbitan Erlangga seri Mandiri terdapat kekurangan, yaitu keluasan materi pada Bab I terlalu luas dan pada bab IV terdapat materi yang kurang.

Materi pada buku teks terbitan Kemendikbud dan terbitan Erlangga seri Mandiri sudah sesuai dengan indikator penilaian kedalaman materi, yaitu materi pada buku teks berisi penjelasan berkaitan dengan konsep, definisi, prinsip,, prosedur, contohcontoh, dan pelatihan agar peserta didik mampu mengenali gagasan atau ide, mengidentifikasi gagasan, menjelaskan ciri suatu konsep atau gagasan, mampu mendefinisikan, mengontruksi 
pengeahuan baru, dan menerapkan pengetahuan sesuai dengan KI dan KD yang telah dirumuskan. Serta, uraian materi sudah sesuai dengan ranah kognitif, afektif, dan psikomotorik yang dituntut dalam KI dan KD.

Keakuratan materi yang dianalisis, yaitu mengenai akurasi konsep dan definisi; akurasi prosedur; akurasi contoh, fakta, dan ilustrasi; dan akurasi soal. Sehingga, buku teks terbitan Kemendikbud dan terbitan Erlangga seri Mandiri sudah sesuai dengan indikator penilaian.

Materi pada kedua buku teks sudah disajikan seccara akurat dan tidak menimbulkan miskonsepsi yang dilakukan oleh peserta didik. Konsep dan definisi wajib dirumuskan dengan tepat guna mendukung tercapainya $\mathrm{KI}$ dan $\mathrm{KD}$. Hal ini bisa dilihat dari setiap materi yang ditampilkan pada setiap bab.

Prosedur wajib dirumuskan secara akurat sehingga peserta didik tidak melakukan kekeliruan secara sistematis. Pada buku teks terbitan Kemendikbud, contoh akurasi prosedur dapat dilihat dari adanya peta konsep yang ada di setiap awal bab, sedangkan buku teks terbitan Erlangga seri Mandiri dapat terlihat pada soal keterampilan.

Materi-materi pada buku teks terbitan Kemendikbud dan terbitan Erlangga seri Mandiri memiliki contoh, fakta, dan ilustrasi yang akurat. Hal ini dibuktikan dari materi yang disajikan pada setiap bab. Setiap bab materi terdapat contoh berupa fakta untuk memperkuat materi yang disajikan, contoh-contoh yang disajikan pada buku teks terbitan Kemendikbud berupa ilustrasi gambar, sedangkan pada buku teks terbitan Erlangga seri Mandiri memberikan contoh berupa teks dan ilustrasi tabel.

Penguasaan peserta didik atas konsep, prinsip, prosedur, atau algoritma perlu dibangun oleh soal-soal yang disajikan secara akurat. Soal-soal yang disajikan akurat dan relevan karena soal-soal yang disajikan mampu mengasah kemampuan dan pemahaman peserta didik mengenai materi yang sudah disajikan sebelumnya.

Penyajian materi yang baik tidak menimbulkan kebingungan bagi peserta didik. Buku teks terbitan Kemendikbud sudah memiliki penyajian materi yang sesuai. Materi yang disajikan tidak terbelit-belit. Materi yang disajikan pada setiap bab runtut dan setiap buku disajikan runtut dari $\mathrm{KD}$ 3.1. dan 4.1. hingga $\mathrm{KD}$ 3.4. dan 4.4.. buku teks terbitan Kemendikbud didukung materi yang memotivasi, sedangkan pada buku teks terbitan Erlangga seri Mandiri masih kurang.
Evaluasi yang dikembangkan pada Buku Teks Pelajaran IPS Kelas VII Kurikulum 2013 di SMP Sekecamatan Ngargoyoso Kabupaten Karanganyar

Evaluasi yang dikembangkan pada buku teks yang digunakan di SMP Negeri 1 Ngargoyoso dan SMP Negeri 2 Ngargoyoso, yaitu ranah kognitif dan ranah psikomotorik.. Ranah afektif sendiri terdapat secara tersirat, yaitu bisa diambilkan dari sikap ketika pengerjaan soal-soal ranah kognitif dan psikomotorik. Evaluasi pada ranah kognitif sendiri terdapat dalam soal-soal yang tersaji pada setiap akhir bab. Ranah psikomotorik pada buku teks terbitan Kemendikbud terdapat pada setiap materi, sedangkan pada buku teks terbitan Erlangga seri Mandiri terdapat pada akhir setiap bab.

Indikator penilaian evaluasi, meliputi (1) soal sesuai dengan Kompetensi Dasar; (2) soal menggunakan stimulus yang menarik (baru, mendorong peserta didik untuk membaca); (3) soal menggunakan stimulus yang kontekstual (gambar/grafik, teks, visualisasi, dll sesuai dengan dunia nyata), (4) mengukur level kognitif (C1-C6) menggunakan taksonomi Anderson, (5) jawaban tersirat pada stimulus, dan (6) mengukur level psikomotorik (P1-P5) menggunakan taksonomi yang dikembangkan oleh Bloom.

Hasil penelitian menunjukkan pada buku teks terbitan Kemendikbud pada indikator (1) soal sesuai dengan KD, seluruh soal sudah sesuai; (2) terdapat 7 soal yang menggunakan stimulus yang menarik; (3) terdapat 7 soal yang menggunakan stimulus yang kontekstual; (4) level kognitif $\mathrm{C} 1$ terdapat 12 soal, $\mathrm{C} 2$ terdapat 38 soal, C3 terdapat 23 soal, C4 terdapat 6 soal, dan C5 terdapat 1 soal; (5) terdapat 7 soal yang memiliki jawaban tersirat pada stimulus; dan (6) level psikomotorik, soal-soal pada level P2 dan P3.

Buku teks terbitan Erlangga seri Mandiri pada indikator (1) seluruh soal sudah sesuai dengan $\mathrm{KD}$; (2) terdapat 17 soal menggunakan stimulus yang menarik; (3) terdapat 17 soal yang menggunakan stimulus yang kontekstual; (4) level kognitif, $\mathrm{C} 1$ terdapat 72 soal, C2 terdapat 98 soal, C3 terdapat 17 soal, C4 terdapat 13 soal, dan C6 terdapat 4 soal; (5) terdapat 17 soal yang memiliki jawaban tersirat pada stimulus; dan (6) level psikomotorik, bervariasi dari level P1 hingga P5.

Soal-soal kognitif yang disajikan pada kedua buku sama-sama masih pada level medium. Dilihat dari soal-soal kognitif pada buku teks terbitan Kemendikbud mayoritas soal 
pada pada level C2 dengan persentase 47,5\% dan pada buku teks terbitan Erlangga seri Mandiri mayoritas soal pada level C2 dengan persentase yang sama, yaitu $48 \%$.

Soal-soal HOTS sendiri pada buku teks terbitan Kemendikbud memiliki persentase $8,75 \%$ dan pada buku teks terbitan Erlangga seri Mandiri memiliki persentase 8,33\%. Helmawati (2018) membagi persentase penilaian pembelajaran pada aspek kognitif, yaitu level C1 sebanyak $5 \%$, tetapi pada buku kedua buku teks memiliki persentase lebih dari 5\%, berikut seterusnya pada level C2. Sedangkan, untuk level C3 sebanyak 45\% tetapi pada kedua buku kurang dari angka tersebut. Level HOTS memiliki persentase $25 \%$ untuk level C4, sedangkan pada buku teks terbitan Kemendikbud memiliki persentase 7,5\% dan buku teks terbitan Erlangga seri Mandiri 6,37\%. Level C5 hanya terdapat satu soal pada buku teks terbitan Kemendikbud, sedangkan pada buku teks terbitan Erlangga seri Mandiri tidak ada. Serta, pada level C6 pada buku teks terbitan Kemendikbud tidak ada, sedangkan pada buku teks terbitan Erlangga seri Mandiri terdapat empat soal dan soal tersebut terdapat pada penugasan.

Soal-soal yang disajikan pada buku teks terbitan Kemendikbud dan terbitan Erlangga seri Mandiri masih didominasi pada level medium. Hal ini sejalan dengan penelitian yang dilakukan Jannah dan Ernawati (2020) yang menunjukkan hasil penelitian bahwa level kognitif soal yang dominan berada pada level MOTS dengan persentase $62 \%$ dengan kategori soal berada pada level C2 dan C3.

Tanggapan Guru terhadap Buku Teks Pelajaran IPS Kelas VII Kurikulum 2013 di SMP Sekecamatan Ngargoyoso Kabupaten Karanganyar

Ibu Lastri dan Ibu Wiwin beranggapan bahwa materi pada buku teks ynag mereka gunakan sudah memiliki kelengkapan materi sesuai dengan tuntutan KI dan KD. Jika dilihat dari kelengkapan materi, Ibu Lastri menjelaskan bahwa lebih lengkap buku teks terbitan terbitan Kemendikbud. Tetapi, penjabaran materi lebih detail pada buku teks Erlangga seri Mandiri.

Ibu Lastri menanggapi bahwa buku teks terbitan Erlangga seri Mandiri dari segi konsep dan definisi lebih lengkap, sedangkan untuk contoh-contoh lebih banyak pada buku teks terbitan Kemendikbud. Tangggapan dari ibu Wiwin sendiri mengenai keluasan buku teks terbitan Kemendikbud, yaitu bahawa penyampaian konsep sudah cukup.
Kedalaman materi buku teks pelajaran IPS terbitan Kemendikbud tidak hanya memberikan definisi suatu konsep saja tetapi juga menjelaskan lebih rinci. Hal ini memiliki kesamaan tanggapan dari ibu Lastri dan ibu Wiwin.

Buku teks pelajaran IPS yang digunakan di SMP Negeri 1 Ngargoyoso sudah memiliki keakuratan konsep dan definisi hal ini seperti tanggapan dari ibu Lastri menjelaskan buku teks terbitan Kemendikbud dan terbitan Erlangga seri Mandiri memiliki keakuratan materi dapat dilihat dari daftar pustaka yang memiliki banyak referensi. Tetapi, untuk akurasi prosedur, ibu Lastri beranggapan bahwa secara prosedural buku teks terbitan Kemendikbud sudah prosedural karena terdapat peta konsep, sehingga pembelajaran lebih terarah. Sedangkan, pada buku teks terbitan Erlangga seri Mandiri tidak ada. Akurasi contoh sudah sesuai dengan lingkungan peserta didik sehingga ibu Lastri dan ibu Wiwin beranggapan sama.

Penyajian materi yang baik tidak menimbulkan kebingungan bagi pembaca. Berdasarkan wawancara dengan ibu Lasri dan ibu Wiwin, mereka memberikan tanggapan bahwa penyajian materi pada buku teks pelajaran IPS terbitan Kemendikbud memiliki penyajian yang baik, bahasa yang digunakan tidak terbelit-belit, dan materi disampaikan mudah dipahami oleh peserta didik. Tambahan dari ibu Lastri, yaitu apabila peserta didik membaca dengan teliti, maka tidak akan menimbulkan kesulitan dan kebingungan untuk membaca dan memahami buku teks terbitan Kemendikbud maupun buku teks terbitan Erlangga seri Mandiri.

Materi pada buku teks pelajaran IPS terbitan Kemendikbud dan terbitan Erlangga seri Mandiri sudah didukung dengan materi yang memotivasi. Hal ini disampaikan oleh ibu Lastri dengan dukungannya berupa ditampilkan ilustrasi-ilustrasi berupa gambar. Dengan adanya gambar dapat memotivasi peserta didik untuk menimbulkan rasa ingi tahu. Kemudia, dari rasa ingin tahu menimbulkan rasa ingin membaca peserta didik. Sedangkan ibu Wiwin menyampaikan bahwa penyajian materi untuk buku terbitan Kemendikbud ini tidak merasa kesulitan untuk mengajar. Beliau beranggapan materi terlihat sedikit tetapi penjabarannya luas.

Buku teks terbitan Kemendikbud dan terbitan Erlangga seri Mandiri sudah terdapat penilaian pengetahuan dan keterampilan. Ibu Lastri dan ibu Wiwin sependapat bahwa soalsoal pada buku teks yang mereka gunakan 
dalam pembelajaran IPS memiliki level soal kognitif pada level medium.

Buku teks pelajaran IPS dari soal keterampilan, ibu Lastri dan ibu Wiwin beranggapan bahwa soal-soal tersebut mampu mengasah kemampuan peserta didik dalam kreativitas dan menimbulkan keaktifan peserta didik karena soal-soal yang disajikan mengharuskan peserta didik untuk bergerak.

Ibu Lastri dan ibu Wiwin sama-sama memberikan tanggapan bahwa buku teks pelajaran IPS yang mereka gunakan sudah bisa membantu dalam mencapai tujuan pembelajaran IPS yang sesuai dengan Kurikulum 2013. Hal ini sependapat dengan hasil penelitian yang dilakukan oleh Agusfina, dkk (2018) memiliki kesimpulan bahwa aspek materi dan aspek penyajian dari kesembilan guru bahasa Indonesia terhadap buku teks bahasa Indonesia kelas VII sudah sesuai dengan kurikulum 2013 dan dapat digunakan peserta didik untuk belajar.

\section{SIMPULAN}

Berdasarkan hasil penelitian yang diperoleh dapat disimpulkan sebagai berikut. Pengembangan materi dilihat dari cakupan materi, keluasan materi, kedalaman materi, keakuratan materi, dan penyajian materi sudah sesuai dengan indikator yang ditetapkan. Cakupan materi sudah memiliki kelengakpan pokok bahasna yang dapat menunjang KI dan KD. Keluasan materi sesuai dengan kebutuhan materi pokok yang mendukung tercapainya $\mathrm{KI}$ dan KD. Materi yang disampaikan sudah berisi penjelasan konsep, definisi, prinsip, prosedur, dan pelatihan supaya peserta didik mampu mengenali gagasan/ide hingga menerapkan pengetahuan. Keakuratan materi sudah sesuai dari segi akurasi konsep dan definisi, akurasi prosedur, akurasi contoh, fakta, dan ilustrasi, serta akurasi soal. Materi yang disajikan pada kedua buku tidak menimbulkan kebingungan bagi pembaca.

Evaluasi yang dikembangkan pada buku teks terbitan Kemendikbud dan terbitan Erlangga seri Mandiri berupa soal kognitif dan soal psikomotorik. Soal yang disajikan bervariasi dari jenis soal hingga level kognitif serta level psikomotorik.
Tanggapan guru terhadap buku teks di SMP Negeri 1 Ngargoyoso dan SMP Negeri 2 Ngargoyoso memiliki persamaan mengenai tanggapan yang diberikan terhadap buku teks yang mereka gunakan untuk pembelajaran IPS. Ibu Lastri dan ibu Wiwin berpendapat bahwa buku yang mereka gunakan sudah sesuai dengan $\mathrm{KI}$ dan KD yang terbaru meskipun buku teks yang digunakan buku cetakan lama dari segi materi maupun alat evaluasi yang ada di dalamnya.

\section{DAFTAR PUSTAKA}

Agusfina, Fatemah Dela; Susetyo dan Didi Yulistio. 2018. Persepsi Guru Terhadap Buku Teks Bahasa Indonesia Kurikulum 2013 Kelas VII SMP Negeri Kota Bengkulu. Dalam Korpus. Vol. 2. No. 1. Hal. 29-33.

Fajar, Arnie. 2002. Portofolio dalam Pembelajaran IPS. Bandung: PT Remaja Rosdakarya.

Gasong, Dina. 2018. Belajar dan Pembelajaran. Yogyakarta: Deepublish.

Jannah, Rahmatul dan Ernawati. 2020. Analisis Level Kognitif Soal Ujian Akhir Semester (UAS) Geografi Kelas VI Semeser Gasal SMA Negeri Se-Kota Pariaman Tahun Pelajaran 2019/2020 Berdasarkan Taksonomi Bloom Revisi Anderson. Dalam Buana. Vol. 4. No. 6. Hal 12261233.

Muslich, Mansur. 2010. Textbook Writing: Dasardasar Pemahaman, Penulisan, dan Pemakaian Buku Teks. Yogyakarta: Deepublish.

Nurhadi dan Suwardi. 2010. Evaluasi Pembelajaran yang Efektif dan Menyenangkan. Jakarta: Multi Kreasi Satudelapan.

Purnomo, Arif, dkk. 2020. Teaching Controversial Issues in Social Studies Class to Develop Critical Thinking and Social Analysis Ability. Dalam International Journal of Reseacrh and Review. VO. 7. No. 6. Hal. 371-382.

Ramda, Apolonia Hendrice. 2017. Analisis Kesesuaian Materi pada Buku Teks Matematika Kelas VII dengan Kurikulum 2013. Dalam Phythagoras: Jurnal Pendidikan Matematika. Vol. 12. No. 1. Hal 12-22. 